\title{
Seed Priming in Vegetable Crops: A Review
}

\author{
Dipika Mal*, Jyoti Verma, Adarsh Levan, M.R. Reddy, A.V. Avinash \\ and Pavan Kumar Velaga
}

Lovely Professional University

*Corresponding author

\section{Ke yw ords \\ Seed priming, Crop establishment, Germination, Vegetable crops and Yield}

\section{Article Info}

Accepted:

10 May 2019

Available Online:

10 June 2019

\section{A B S T R A C T}

Vegetable crops comprise a major part in Indian agriculture in terms of providing food and nutritional security. Recommended per day consumption of vegetables is $300 \mathrm{~g}$. In recent past, Indian agriculture has witnessed a tremendous progress in vegetable production, due to the advent of high yielding varieties and new technologies. Vegetables are important sources of vitamins, minerals and other nutrients of medicinal and therapeutic value. Due to the percent of low germination rate and seedling emergence yield of the crops decreasing day by day. Poor seed germinations and inappropriate crop stand are the main constraints in the production of vegetable crops. Farmers are not having sufficient resources for seedbed preparation for sowing and they are at more risk as compared to progressive farmers. On the other hand good establishment increases competitiveness against weeds, increases tolerance to drought period, increase yield and avoids the time consuming need for re-sowing that is costly too. Seed priming increase the percent of germination and reduce the time of seedling emergence side by side improve the crop stand. A method to improve the rate and uniformity of germination is the priming or physiological advancement of the seed lot. Seed priming is the method of improve germinations and uniform emergence of seedlings in field conditions. Although it will improve the vigour and crop establishment and finally enhance the yield. It is a very low cost hydration technique in which seeds are treated with various chemicals or sometimes with normal water also. After treating the seeds are re-dried and show in the field. Seed priming is generally adopted for better crop stand, germination and yield of various vegetable crops.

\section{Introduction}

Vegetables crops are important in human nutrition and its importance in daily nutrition is getting increases all around the world. Rapid germination and emergence of seedlings are essential for successful crop establishment, importance of good and high crop establishment is recognized by researchers and as well as by farmers they are major challenges in successful crop production (Chivasa et al., 1998 and Murungu et al., 2004). Main reasons for the successful crop stand are high germination percent and good vigor of seedlings (Noor et al., 2013). Modern strategic approaches are however 
necessary for sustainable development of crops so as to meet increasing demand in both domestic and export market (Soubhagya Behera, 2016). Research on techniques for improving the germination, growth and yield of crop species has been done for many years. For successful crop establishment seed priming could play a vital role in crop production. Seed priming was first proposed by Heydecker in year 1973. It is a cost effective technique to ensure uniform emergence and high vigourity of seeds which is leading to better crop establishment and yield. It is a simple, effective and low cost technique in which seeds are partially hydrated to a point where pre-germination metabolic activities start without actual germination by treating with different chemicals or growth regulators, and then redried until close to the original dry weight. In crop production, stand establishment determines plant density, uniformity, and management options. For expensive hybrid vegetable seeds, it is particularly important that seeds germinate rapidly and uniformly, tolerate adverse germination conditions, and produce normal seedlings. Seed vigor has been proved to be the primary factor governing seed quality, in the context of successful stand establishment. Hence seed invigouration or enhancement of seed vigor has been a major area of interest for researchers, owing to its high industrial and economic implications. Seed invigouration is a post-harvest, pre-sowing technique for improvement of seedling emergence and stand establishment. The most promising invigouration technique for improving the rate and uniformity of plant stand is seed priming (Pandey et al., 2017).

\section{Type of seed priming}

Seed priming techniques includes: hydropriming, halo-priming, osmo-priming, hormonal priming, solid matrix priming and biopriming. Seed priming improves germination percentage of seed (Kausar et al., 2009). In hydro-priming technique only water is used to prime the seeds where water penetrate freely into seed. In solid matrix priming technique the seed hydration is controlled by adding solute with water (Pill and Necker, 2001). Osmopriming strengthens the antioxidant system and increases seed germination potential, resulting in an increased stress tolerance in germinating seeds (Chen and Arora, 2011). Various seeds are affected by priming duration (Arif et al., 2008), priming agent (Farooq et al., 2005) and oxygen supply to seed (Nascimento, 2003).

\section{Hydro-priming}

Soaking the seeds in water before sowing which may or may not be followed by air drying of the seeds. Hydro-priming may enhance seed germination percentage and seedling emergence under both saline and non- saline conditions (Roy and Srivastava, 1999).

\section{Halo-priming}

In this technique seeds are soaking in solution of inorganic salts i.e. $\mathrm{NaCl}, \mathrm{KNO}_{3}, \mathrm{CaCl}_{2}$ and $\mathrm{CaSO}_{4}$ etc. A number of studies have shown a significant improvement in seed germination, seedling emergence and establishment and final crop yield in salt affected soil in response to halo-priming (Khan et al., 2009).

\section{Osmo-priming}

It is a technique where seeds are soaked in sugar solution in PEG for a certain period followed by air drying of seeds before sowing. This technique improves germination under non-saline or saline conditions (Salehzade et al., 2009). 


\section{Hormonal priming}

In hormonal priming seeds are treated with different plant growth hormones like GA3, kinetin, NAA and ascorbate etc. This is basically a presoaking treatments which promotes the growth and development of the seedlings (Ashraf et al., 2001).

\section{Solid matrix priming}

This is techniques or method in which seeds are mix with wet solid water basically water uptake by seeds can be controlled. Afterward, seeds are separated from matrix and washed thoroughly and dried. When seeds are gone through this process natural imbibition process of the soil stimulated and seeds are hydrate slowly. Vermiculite, peat moss, charcoal, sand, clay and some exemplary solid carries applied in solid matrix priming.

\section{Bio-priming}

In this method seeds are mainly inoculated with bacterial inoculation. The seed bio priming is not only involves in germination and seedling emergence of crop plants but also involves in protection of seeds against soil borne pathogens. Seed hydration may occur during priming and seeds are infected by pathogens it may results in a stronger microbial growth and consequently impairment of plant health. The best ecological approaches to overcome this kind of problems are applying antagonistic microorganism during seed priming. Even some bio control agents or bacteria can support the seeds or plant after germination by colonizing rhizosphere. It can be consider that bio priming is the effective method approach of disease management than other techniques such as film coating and pelleting. Bio-priming with rhizobacteria improved germination parameters of radish seeds under saline conditions. In recent days the use of bio-priming with plant growth-promoting bacteria (PGPB) as an integral component of agricultural practices.

\section{Effect of hydro-priming on vegetable crops}

Hydro-priming is most commonly used method of seed priming. Hydro-priming is achieved by continuous or successive addition of a limited amount of water to the seeds. Hydro-priming is a very important technique which results in rapid germination, improved seed growth and uniform stand establishment in various crops (Adebisi et al., 2013). Sikhondze and Ossom (2011) conducted an experiment to determine how long okra seeds should be primed in order to influence seedling growth and development. Four time durations $(6,12,24$, or 36 hours) were taken for hydro priming okra seeds. The results showed that seedlings grown from seeds that are primed for 24 hours had the greatest mean stem length and diameter, as compared to other durations and control. Tajbakhsh et al., (2004) conduct experiment on onion carried different treating methods. The results indicated that hydro-priming in high humidity leads to shortening the average germination time. Kaur et al., (2002) found that priming of pea by water and mannitol (4\%) for 12 hours at $25^{\circ} \mathrm{C}$ increased the number and biomass of plants knots. The positive effect of hydro priming may be due to the maintenance of tissue water content, increase in antioxidant activities and carbohydrate metabolism (Farooq et al., 2008). Hydro-priming of bean seeds in water for 7-14 hours can improve the plant performance (Ghassemi-Golezani et al., 2010). Sharma et al., (2013) reported that he has taken four different priming methods like hydro-priming, osmopriming, halo-priming and solid matrix along with control. The hydro-priming technique for 12 hour duration and SM priming with calcium aluminum silicate for 24 hour significantly increased the seed germination, seedling vigour, mean 
germination time and marketable fruit yield. Priming in seed improve seed germination, seedling vigour and fruit yield in okra.

\section{Effect of halo-priming on vegetable crops}

Halo-priming- soaking the seeds in salt solutions. Yadav et al., (2012) conducted an experiment on 15 genotypes of okra plant where seeds were treated with three priming solutions in three replications. Three primers used for seed treatments were hydropriming, halopriming with calcium chloride and halopriming with potassium nitrate. The results showed that all seed priming treatments enhance the synchronous germination and speed of germination in genotypes IC411698 and IC89936.KNO3 increases yield, fruit size and improves the quality in field and vegetables crops (Singh 2015). Jianhua and Mcdonald (1997) reported that in case of accelerated aged seeds, halopriming for small-seeded crops is established as best method of priming and is capable of improving seed germination. It is evident from table 1 that significantly maximum increase in seedling length occurs in T6 Poly Ethylene Glycol 5\% for $12 \mathrm{hrs}$ (40.18) followed by T4 Poly $\mathrm{NaCl} 2 \%$ for 12 hrs (38.24\%) while lowest seedling length T0 $(13.87 \%)$ was observed with unprimed control treatment.

\section{Effect of osmo-priming on vegetable crops}

Araby and Hegazi (2004) studied osmopriming effect of PEG in tomato seeds and observed the best results with a priming duration of 7 days and direct sowing. Lin and Sung (2001) reported that pre-sowing treatments such as osmopriming and hydropriming in the bitter gourd seeds before sowing overcame sub-optimal environmental effects on germination and subsequent seedling establishment. Singh et al., (2014a) reported the effect of osmo-priming duration on germination, emergence and early growth of cowpea in Nigeria. Treatment consisted three osmo-priming duration (soaking in $1 \%$ KNO3salt for 6,8 and $10 \mathrm{hrs)}$ and one hydroprimed control (10hr). The results showed that osmo-priming with $\mathrm{KNO}_{3}$ for different durations were superior to unprimed treatment in term of seed germination, emergence, plant height and dry matter accumulation in cowpea. Primed seeds (both osmopriming and hydro-priming) increased performance of cowpea.

Table.1 Mean performance data for five seedling characters in Bitter gourd (Momordica charantia L.)

\begin{tabular}{|l|l|c|c|c|c|c|}
\hline S.No. & \multicolumn{1}{|c|}{ Treatment } & $\begin{array}{c}\text { Germinatio } \\
\mathbf{n}(\mathbf{\%})\end{array}$ & $\begin{array}{c}\text { Speed of } \\
\text { germination }\end{array}$ & $\begin{array}{c}\text { Shoot } \\
\text { length(cm) }\end{array}$ & $\begin{array}{c}\text { Root } \\
\text { Length(cm) }\end{array}$ & $\begin{array}{c}\text { Seedling } \\
\text { length }\end{array}$ \\
\hline $\mathbf{1 .}$ & T0- Unprimed Control & 67 & 3.75 & 5.56 & 8.30 & 13.87 \\
\hline $\mathbf{2 .}$ & $\begin{array}{l}\text { T1- Distilled water } \\
\text { hydration (for 6 hrs) }\end{array}$ & 72 & 7.0 & 8.78 & 12.45 & 21.26 \\
\hline $\mathbf{3 .}$ & $\begin{array}{l}\text { T2- Distilled water } \\
\text { hydration (for 12 hrs) }\end{array}$ & 74 & 8.0 & 10.12 & 15.05 & 25.18 \\
\hline $\mathbf{4 .}$ & T3- NaCl (for 6 hrs) & 79 & 9.50 & 15.40 & 18.20 & 33.60 \\
\hline $\mathbf{5 .}$ & T4- NaCl (for 12 hrs) & 80 & 13.0 & 17.30 & 21.15 & 38.24 \\
\hline $\mathbf{6 .}$ & T5- PEG (for 6 hrs) & 85 & 10.50 & 16.22 & 20.52 & 36.25 \\
\hline 7. & T6- PEG (for 12 hrs) & 87 & 18 & 18.20 & 21.90 & 40.18 \\
\hline
\end{tabular}

Source: Saini et al., (2017) 
Table.2 Effect of seed priming on treatments on germination percent of tomato varieties

\begin{tabular}{|c|c|c|c|c|}
\hline Primimg Treatment & UtkalPragyan & UtkalKumari & Utkal Raja & UtkalDeepti \\
\hline $\mathrm{GA}_{3}(1 \mathrm{ppm})$ & 90.00 & 94.00 & 92.00 & 93.66 \\
\hline $\mathrm{KNO}_{3}(5 \%)$ & 88.00 & 90.66 & 90.00 & 91.33 \\
\hline $\mathrm{Na}_{2} \mathrm{HPO}_{4}(2 \%)$ & 85.00 & 87.00 & 88.33 & 88.00 \\
\hline PEG(10 \%) & 81.33 & 81.67 & 81.00 & 90.66 \\
\hline $\mathrm{ZnSO}_{4}(1 \%)$ & 81.00 & 82.67 & 81.33 & 84.00 \\
\hline Ascorbic Acid(50 ppm) & 76.00 & 79.33 & 79.00 & 77.00 \\
\hline Deionised $\mathrm{H}_{2} \mathrm{O}$ & 78.00 & 80.66 & 80.00 & 78.33 \\
\hline Dry Seed (Control) & 71.00 & 72.00 & 71.66 & 71.33 \\
\hline
\end{tabular}

Source: Soubhagya Behera (2016)

However, osmo-priming with $\mathrm{KNO}_{3}$ salt (soaked in $1 \% \mathrm{KNO}_{3}$ salt solution and dried before sowing) for 6 hours could result in greater seed germination and seedling height than hydro-priming.

\section{Effect of hormonal priming on germination of vegetable crops}

Soubhagyabehera, 2016 reported when tomato seeds were primed with GA3 in Utkal Kumari germination was increased by $30.56 \%$. Venkatasubramanian and Umarani (2010) conducted storage studies to compare four different methods of priming viz., hydropriming, halopriming, sand matrix priming and osmopriming accomplished for two durations. The results revealed that viability of primed seeds were dependent on the method as well as duration of priming. Among the protocols studied, hydropriming (48 hours) for tomato and sand matrix priming (80\% water holding capacity, 3 days) for eggplant and chilli were established as best methods of seed priming. Treatment capable of improving seed vigour as well as viability (Table 2).

Effect of seed priming on flowering of vegetable crops

Satishkumar (2005) reported that when brinjal seed treated with osmopriming solution increase the number of leaves, plant height, fruit yield, fruit length and days of $50 \%$ flowering also minimize.

It can be concluded that from this review Seed priming controls the hydration level of seed and also controls the metabolic activity within the seed which is necessary for seed germination. Seed priming not only done with chemical and plant growth regulators it also can be done with antagonistic microorganisms which can be reduce soil and seed borne pathogens. Seed priming is not only adopted to improve uniform seed germination of different vegetable crops under nonsupporting conditions but also used to reduce the different diseases.

\section{References}

Adebisi M A, Kehinde T O, Abdul-Rafiu M A, Esuruoso O A, Oni O D and Ativie O. 2013. Seed physiological quality of three Capsicum species as affected by seed density andhydropriming treatment durations. Journal of Agronomy, 12: 3845.

Araby MM and Hegazi AZ. 2004. Response of tomato seeds to hydro- and osmopriming, and possible relations of some antioxidant enzymes and endogenous polyamine fractions. Egyptian Journal Biology, 6: 81-93. 
Arif, M.T. Jan, B.K. Marwat and A.M. Khan. 2008. Seed priming improves emergence and yield of soybean. Pakistan J. Bot., 40(3): 1169-1177.

Chen, K. and R. Arora. 2011. Dynamics of the antioxidant system during seed osmopriming, post priming germination, and seedling establishment in spinach (Spinacia oleracea). Plant Sci., 180(2): 212-220.

Chivasa, W., Harris, D., Chiduza, C., Nyamudeza, P. and Mashingaidze, A.B. 1998. Agronomic practices, major crops and farmer's perceptions of the importance of good stand establishment in Musikavanhu Communal Area, Zimbabwe. Journal of Applied Science in Southern Af-rica., 4(2), 108-125.

Farooq, M., S.M.A. Basra, B.A. Saleem, M. Nafees and S.A. Christi. 2005. Enhancement of tomato seed germination and seedling vigor by osmopriming. Pakistan J. Agri. Sci., 42: 34.

Ghassemi-Golezani K, Chadordooz-Jeddi A, Nasrullahzadeh S, Mohammad $\mathrm{M}$. 2010. Influence of hydro-priming duration on field performance of pinto bean (Phaseolus vulgaris L.) cultivars. African Journal of Agricultural Research, 5(9), 893-897.

Kaur S, Cupta AK, Kaur N. 2002. Effect of osmo and hydropriming of chickpea seeds on the performance of crop in the field. International Chickpea and Pigeonpea. Newsletter 9, 1517.

Kausar, M., T. Mahmood, S.M.A. Basra and M. Arshad. 2009. Invigoration of low vigor sunflower hybrids by seed priming. Int. J. Agric. Biol., 11(5): 521528

Khan, H. A., Ayub, C. M., Pervez, M. A., Bilal, R. M., Shahid, M. A. and Ziaf, K. 2009. Effect of seed priming with $\mathrm{NaCl}$ on salinity tolerance of hot pepper (Capsicum annuum L.) at seedling stage. Soil Environ., 28: 81-87.

Lin J M and Sung J M. 2001. Presowing treatments for improving emergence of bitter gourd seedlings under optimal and sub-optimal temperatures. Seed Science and Technology 29: 39-50.

Murungu, E.S., Chiduza, C., Nyamugafata, P., Clark, L.J. and Whalley, W.R. 2004. Effect of on farm seed prim-ing on emergence, growth and yield of cotton and Maize in a semi-arid area of Zimbabwe. Experimental Agriculture., 40(1): 23-36.

Nascimento, W.M. 2003. Muskmelon seed germination and seedling development in response to seed priming. Scientia Agricola., 60: 71-75.

Noor-un-nisamemon, Moulabuxgandahi, VajantimalaPahoja and Nasimshar. 2013. Response of seed priming with boron on germination and seedling sprouts of broccoli. International Journal of Agricultural Science, 3(2): 183-194.

Pill, W.G. and A.D. Necker. 2001. The effects of seed treatments on germination and establishment of Kentucky bluegrass (L.). Seed Sci. and Technol., 29(1): 6572.

Pratima Pandey, K Bhanuprakash and Umesh. 2017. Effect of Seed Priming on Seed Germination and Vigour in Fresh and Aged Seeds of Cucumber. International Journal of Environment, Agriculture and Biotechnology (IJEAB), 2(4): 22612264.

Rishabh Saini, Prashant Kumar Rai, Bineeta M Bara, Purooshottam Sahu, Taqui Anjer and Rupesh Kumar. 2017. Effect of different seed priming treatments and its duration on seedling characters of Bitter gourd (Momordica charantia L.). Journal of Pharmacognosy and Phytochemistry, (5): 848-850.

Roy, N. K. and Srivastava, A. K. 1999. Effect of presoaking seed treatment on 
germination and amylase activity of wheat (Triticum aestivumL.) under salt stress conditions. Rachis 18:46 51.

Salehzade, H., Shishvan, M. I., Ghiyasi, M., Forouzin, F. and Siyahjani, A.A. 2009. Effect of seed priming on germination and seedling growth of wheat [Triticum aestivum(L).]. Res J Biol. Sci., 4: 62931.

Satishkumar L. 2005. Influence of presoaking seed treatment and seed pelleting on storability in brinjal (Solanum melongena L.). Ind. Hort., 32: 78-82.

Sharma, A.D., Rathore, S.V.S., Srinivasan, K. and Tayagi, R. 2013. Comparison of various seed priming method for seed germination, seedling vigour and fruit yield in okra [Abelmoschus esculentus (L.) Moench]. Scientia Horticulturae., 165: 75-81.

Sikhondze D K and Ossom E M. 2011. Impact of priming okra (Abelmoschus esculentus L.) seeds on seedling performance in Swaziland. Advances in Environment Biology, 5: 1221- 1228.

Singh, A., Dahiru, R., Musa, M. and Haliru, B. S. 2014a. Effects of osmo-priming duration on germination, emergence and early growth of cowpea [Vigna unguiculata (L.) Walp.] in the Sudan savanna Nigeria. Int J Agron., 4 ID 841238: 4.

Soubhagya Behera, 2016. A study on the effect of hormonal priming (ga3) on seed quality parameters of solanaceous vegetables. International journal of agricultural science and research, 6(3): 337- 348.

Tajbakhsh M, Brown PH, Gracie AJ, Spurr CJ, Donovan N. 2004. Mitigation of stunted root abnormality in onion (Allium cepaL.) using seed priming treatments. Seed Science and Technology, 32(3): 686-692.

Venkatasubramanian A and Umarani R.2010. Storability of primed seeds of tomato (Lycopersicon esculentum), eggplant (Solanum melongena) and chilli (Capsicum annum). Madras Agricultural Journal, 97: 117-124.

Yadav S K, Kumar D, Kumar V, Hussain Z, Sharma A D and Kumar A. 2012. Seed priming effects on diverse germplasm of okra [Abelmoschus esculentus (L.) Moench]. Vegetos, 25:202-209.

\section{How to cite this article:}

Dipika Mal, Jyoti Verma, Adarsh Levan, M.R. Reddy, A.V. Avinash and Pavan Kumar Velaga. 2019. Seed Priming in Vegetable Crops: A Review. Int.J.Curr.Microbiol.App.Sci. 8(06): 868874. doi: https://doi.org/10.20546/ijcmas.2019.806.105 